\title{
ANALISIS PENDAPATAN DAN PERLINDUNGAN HAK-HAK BURUH TANI HARIAN LEPAS (BTHL) DI KAB. KARO SUMATERA UTARA
}

\author{
Oleh: \\ Rosmawati Br. Bangun ${ }^{1)}$ \\ Matius Bangun ${ }^{2)}$ \\ Universitas Darma Agung, Medan ${ }^{1,2)}$ \\ E- mail: \\ rosbrbangun58@gmail.com 1)

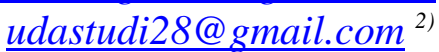

\begin{abstract}
This study aims at seeing and learning the income of the Daily Lepas Farmer (BTHL) as well as the protection carried out by the Regional Government for the BTHL. This research was carried out in Berastagi Subdistrict, Karo Regency and the method used is qualitative by collecting data from interviews, field observations, literary studies, mass media, and documentation.The results of the research show that the income levels of Vegetable Farmers () BTSy, Fruit Farmers (BTBb) and Flower Farmers (BTBg) show differences that are not too high. The average result, BTSy income is Rp. 2,375,000 - BTBb of Rp. 2,556,700, - BTBg of $R p$. 2,450,762, - (rounding off). The BTSy average income is Rp. 2,375,000, - (100.00) which consists of Main income of $R p$. 1,800,750, - (75.82\%), from the main part-time additional income of Rp. 410,000, - (17.26\%) and part-time income of Rp. 164,245, (06.92\%).The average BTBb income source is Rp. 2,556,700, - (100.00) which consists of main income of $R p .2,236,601$, - (87.48\%), the main part-time income of Rp. 231,669, $(09.06 \%)$ and non-agricultural side income of $R p .111,570,-(04.37 \%)$ BTBg revenue of $R p$. 2,450,762, - (100.00) consisting of Main income of Rp. 2,001,924, - (81.69\%), income from main part time Rp. 331,669, - (13.53\%) and side income from outside agriculture is $R p$. 117,169, - (04.78\%).The protection that is carried out by the Karo Regency Government for casual daily laborers in accordance with Article 99 (1) is only implemented in the Family Planning service while Child Care and the creation of a Labor Settlement are only at the planning stage. Protection as referred to in Law Number 24 of 2011 concerning Social Security Administering Bodies (BPJS), both Health Insurance and Employment Security for Casual Daily Farm Workers (BTHL) who work for companies and have not regulated BRHL working in individual or household businesses.
\end{abstract}

Keywords: Income, Farm Worker Protection, Freelance Daily

\begin{abstract}
ABSTRAK
Penelitian ini di laksanakan di Kecamatan Berastagi Kabupaten Karo dengan tujuan adalah melihat dan mempelajari tentang pendapatan Buruh Tani Harian Lepas (BTHL) serta perlindungan yang di lakukan oleh Pemerintah Daerah terhadap BTHL tersebut. Metode yang digunakan adalah kualitatif dengan pengumpulan data dari hasil wawancara, observasi lapangan, studi litratur, media masa, dan dokumentasi. Hasil peneltian menunjukkan bahwa Tingkat Pendapatan Buruh Tani Sayur ()BTSy, Buruh Tani Buah (BTBb) maupun Buruh tani Bunga (BTBg) menunjukkan perbedaan yang tidak terlalu tinggi. Hasil rata rata , pendapatan BTSy sebesar Rp 2,375,000- BTBb sebesar Rp. 2.556.700,- BTBg sebesar Rp. 2.450.762,(pembulatan).Adapun pendapatan rata rata BTSy sebesar Rp. 2,375.000,- $(100,00)$ yang terdiri dari pendapatan Utama sebesar Rp. 1.800,750,- (75.82\%), dari pendapatan tambahan sambilan utama yaitu sebesar Rp. $\quad 410.000,-(17.26 \%)$ dan pendapatan sambilan sebesar Rp. 164.245,- (06.92 \%). Adapun sumber pendapatan rata rata BTBb sebesar Rp. 2.556,700,-


$(100,00)$ yang terdiri dari pendapatan Utama sebesar Rp. 2.236.601,- $(87.48 \%)$, pendapatan sambilan utama sebesar Rp. 231.669,- $(09,06 \%)$ dan pendapatan sambilan non pertanian sebesar Rp. 111.570,- (04.37 \%) Pendapatan BTBg sebesar Rp. 2.450.762,- $(100,00)$ terdiri dari pendapatan Utama sebesar Rp. 2.001,924,- (81.69\%), pendapatan dari sambilan utama Rp.331.669,- (13.53\%) dan pendapatan sambilan dari luar pertanian sebesar Rp. 117.169,(04.78 \%). Perlidungan yang di lakukan Pemerintah Kabupaten Karo terhadap buruh harian lepas sesuai dengan Pasal 99 (1) baru terlaksana pada pelayanan Keluarga Berencana sementara Penitipan Anak dan pembuatan Pemukiman Buruh baru pada tahap rencana.Perlindungan sebagaimana di maksud dalam Undang Undang Nomor 24 tahun 2011 tentang Badan Penyelenggraan Jaminan Sosial (BPJS) baik Jaminan Kesehatan dan Jaminan Ketenagkerjaan terhadap Buruh Tani harian Lepas (BTHL) yang bekerja di perusahaan dan belum mengatur tentang BRHL yang bekerja di usaha perorangan atau rumah tangga.

Kata Kunci : Pendapatan, Perlindungan Buruh Tani, harian Lepas

\section{PENDAHULUAN \\ 1.1 Latar Belakang}

Sektor Ketenagakerjaan adalah merupakan salah satu sektor yang sangat signifikan pengaruhnya terhadap perekonomian baik daerah maupun nasional. Disamping untuk perekonomian pribadi, keluarga, daerah dan nasional juga merupakan kewajiban seseorang untuk bekerja sehingga dapat mencukupi kebutuhan sehari-hari baik untuk pribadi maupun keluargannya khususnya bagi yang sudah berumah tangga. Hal ini di tekankan dalam Pasal 5 UU No. 13 tahun 2003 tentang Ketenagakerjaan bahwa setiap tenaga kerja memiliki kesempatan yang sama tanpa diskriminasi dalam memperoleh pekerjaan. Khusus untuk buruh dalam pasal 6 tersebut bahwa setiap buruh berhak memperoleh perlakuan yang sama tanpa diskriminasi dari pengusaha.

Di Kabupaten Karo khususnya di Kecamatan Berastagi adalah salah satu daerah pertanian yang juga daerah pariwisata yang sering di sebut Agrowisata. Pada sektor ini banyak tenaga kerja atau buruh tani yang sifatnya harian lepasa karena sifat dari pekerjaan itu sendiri yang sangat fluktuatif. Produksi pertanian yang menjadi penarik wisata adalah buah, sayur dan bunga yang banyak di jumpai di Kecamatan Berastagi.

Tenaga kerja khususnya buruh adalah bagian yang terlemah dari struktur produksi dalam usaha termasuk usaha pertanian. Buruh sering mendapatkan eksploitasi atas ketidak berdayaannya untuk memiliki kesempatan dengan tenaga kerja lainnya, demikian juga dalam mengakses informasi tentang hak haknya sebagai buruh. Hal yang lebih sering terjadi adalah bagi Buruh tani harian Lepas (BTHL) yang sering di peralakukan semena mena untuk eksploitasi dirinya. BTHL inilah yang menjadi fokus dalam penelitian ini.

\subsection{Rumusan Masalah}

Berdasarkan uraian dari Latar Belakang tersebut di atas maka Rumusan Masalah dalam penelitian ini dapat diuraikan sebagai berikut :

a. Dari mana saja sumber pendapatan dari Buruh Harian Lepas (BTHL) dalam memenuhi kebutuhan dasar (primer) hidupnya.

b. Bagaimana upayaperlindungan terhadap terhadap hak-hak Buruh Harian Lepas sektor Pertanian di KecamatanBerastagi, Kabupaten Karo.

\subsection{Tujuan Penelitian}

a. Untuk menganalisis besar dan sumber pendapatan dari Buruh Tani Harian Lepas (BTHL) sektor Pertanian di Kabupaten Karo. 
b. Menganalisis upaya upaya yang di lakukan oleh Pemerintah Kabupaten Karo terhadap Karo hak hak buruh harian lepas sektor pertanian tersebut.

\section{TINJAUAN PUSTAKA}

\subsection{Buruh Tani}

Adapun cirri-ciri buruh tani yang bekerja dengan upah harian lepas sebagai berikut : a) Buruh tani biasanya dipekerjakan oleh pemilik lahan (majikan) dengan digaji sebagai pekerja harian, b) buruh tani berada ditingkat terendah dalam lapisan masyarakat.; c) buruh tani yang sesungguhnya tidak mempunyai latar belakang kecerdasan, d) tidak terikat sama sekali dengan seseorang atau kelompok orang (Sajogyo, 1995: 113-114).

\subsection{Pendapatan Buruh Tani}

Berdasarkan penggolongannya, Biro Pusat Statistik Republik Indonesia (BPS) tahun 2015 membedakan pendapatan penduduk menjadi 4 golongan yaitu: a) Golongan Sangat Tinggi : Golongan pendapatan sangat tinggi adalah jika pendapatan rata-rata lebih dari $\mathrm{Rp}$. 3.500.000,00 perbulan, b) Golongan pendapatan tinggi adalah jika pendapatan rata-rata antara Rp. 2.500.000,00 s/d sebesar Rp. 3.500.000,00 perbulan, diikuti c) Golongan Pendapatan sedang yaitu pendapatan rata-rata dibawah antara $\mathrm{Rp}$. 1.500.000 s/d Rp. 2.500.000, 00 perbulan dan d) Golongan pendapatan rendah adalah jika pendapatan rata-rata $\mathrm{Rp}$. 1.500.000,00 perbulan. Ari penggolongan ini secara umum buruh tani tergolong pada pendapatan rendah.

\subsection{Kelayakan Hidup}

Abraham Maslow mengelompokkan 5 tingkat kebutuhan manusia, yaitu: a) Kebutuhan dasar fisiologis/ kebutuhan fisik (Physiological Needs) b) Kebutuhan akan rasa aman (Safety Needs) c) Kebutuhan untuk mencintai dan cintai (Love Needs) d) Kebutuhan akan harga diri
(Estem Needs; e) Kebutuhan akan aktualisasi diri (Self Actualization) (Maslow, 1994: 43). Dalam penelitian ini buruh tani harian lepas yang dimaksud adalah pekerja lepas di bidang pertanian karena mereka memiliki sumber pendapatan utama hanya bekerja disektor pertanian, sehingga mereka lebih tepat dikatakan buruh tani meskipun kadang kadang bekerja juga di bidang lain seperti membantu di sektor usaha mikro.

Dalam prilaku dan tingkah lakunya terhadap orang-orang yang diluar dari komunitas kelompoknya, buruh tani pada umumnya dalam prakteknya biasa menyerah saja pada nasibnya, ia ingin memperbaiki keadaannya, tetapi ia tidak tahu caranya, karena itu ia menyerah saja. Kelompok ini biasanya curiga terhadap segala sesuatu yang datang dari luar lingkungannya. Akan tetapi sekalipun kedengarannya bertentangan, pada akhirnya buruh tani itupaling percaya kepada pertimbangan para majikan mereka. Tentu saja kepercayaan itu ada batasnya, tetapi dalam berhubungan dengan mereka, sekurang-kurangnya buruh itu tahu di mana mereka berdiri.

\subsection{Perlindungan Buruh}

Jika merujuk pada konsep negara kesejahteraan maka a) negara harus menjamin tiap individu dan keluarga untuk memperoleh pendapatan minimum untuk memenuhi kebutuhannya, b) negara harus memberikan perlindungan jika individu dan keluarganya dalam situasi rentan,c) semua warga negara harus dijamin untuk memperoleh akses pelayanan sosial dasar seperti pendidikan, pemenuhan gizi,sanitasi dan air bersih. Penilaian Indonesia sebagai negara kesejahteraan yang gagal tidak sekadar menjadi kecemasan belaka tetapi bagaimana mengatasi semua itu dari hilir sampai ke hulu, terutama petani dan buruh tani beserta keluarganya yang rentan secara ekonomi, kesehatan, sanitasi dan pelayanan sosial lainnya. 
Oleh karena itu dalam konsideran UU No. 19 Tahun 2013 tentang perlindungan dan pemberdayaan Petani bahwa kecenderungan meningkatnya perubahan iklim, kerentanan terhadap bencana alam dan risiko usaha, globalisasi dan gejolak ekonomi global, serta sistem pasar yang tidak berpihak kepada petani sehingga petani membutuhkan perlindungan dan pemberdayaan.

\subsection{Penelitian Terdahulu}

Penelitian yang dilakukan Evi Andriani (2019) berjudul Analisis Sumber Sumber Pendapatan Buruh Tani Sawit Di Desa Pasar Seluma Kabupaten Seluma menunjukkan bahwa bahwa sumber pendapatan buruh tani pemanen sawit rakyat terdiri dari sektor pertanian yang dibagi menjadi sektor pertanian on farm (sawah) dan sektor pertanian off farm (buruh tanipemanen sawit rakyat, buruh tani padi, buruh tani cabe).

Analisis Perlindungan Jaminan Sosial bagi Pekerja yang dilakukan oleh Akhmad Purnama (2012) dari Balai Besar Penelitian dan Pengembangan pelayanan Kesejahteraan Sosial (B2P3KS) menunjukkan Program Askesos New Initiative yang dilaksanakan di Kabupaten Pemalang sangat bermanfaat bagi pekerja sektor informal, yaitu terciptanya rasa aman bagi peserta; kemudian Mandapatkan pengganti penghasilan apabila terjadi resiko kecelakaan kerja atau kematian; serta dapat mengurangi beban keluarga dan meningkatkan kebutuhan hidup secara layak.

Rekomendasi yang diajukan Kementerian Sosial RI cq Direktorat Linjamsos untuk melanjutkan melanjutkan program jaminan sosial bahwa diperlukan adanya sosialisasi dan mempersiapkan sarana prasarana yang memadai oleh penyelenggara. Perlu kerjasama antara Kementerian Sosial dengan BPJS Ketenagakerjaan mengenai cakupan program jaminan sosial berupa jaminan kesehatan, jaminan kecelakaan kerja dan jaminan kematian. Peningkatan peran LPA dan Pendamping memotivasi Pekerja Sektor Informal berpenghasilan rendah tentang pentingnya ikut jaminan sosial.

\section{METODE PELAKSANAAN}

\subsection{Metode Penelitian}

Penelitian ini tergolong kedalam penelitian sosial yaitu yang dapat memberikan gambaran tentang fakta fakta sosial yang dapat menuju perubahan terhadap masalah kehidupan. Penelitian sosial tersebut adalah untuk untuk mempermudah dalam membedakan penggunaan metode kualitatif dengan penggunaan metode kuantitatif. Metode kuantitatif bergantung pada penggunaan perhitungan dan prosedur analisis statistika. Dijelaskan oleh Basri (2014) bahwa fokus dari penelitian kualitatif adalah pada prosesnya dan pemaknaan hasilnya. Perhatian penelitian kualitatif lebih tertuju pada elemen manusia, objek, dan institusi, serta hubungan atau interaksi di antara elemen-elemen tersebut, dalam upaya memahami suatu peristiwa, perilaku, atau fenomena.

\subsection{Sumber Data}

Sumber data dalam penelitian ini terbagi menjadi dua yaitu data primer dan data sekunder. Data primer adalah data yang diperoleh peneliti secara langsung (dari tangan pertama) yaitu dari buruh tani dan orang orang yang terkait seperti pemilik lahan, pemilik pondokan, pedagang sayur mayur, pedagang asongan, pemilik toko yang menjadi langganan buruh dan lain sejenisnya. Data primer juga di peroleh dari hasil wawancara dengan beberapa informa seperti lurah dan kepala desa yang berada pada daerah penelitian. Sementara data sekunder adalah data yang diperoleh peneliti dari sumber yang sudah ada seperti kantor pemerintahan (lurah / desa, kantor kecamatan, dinas kabupaten, kantor Badan Pusat statistik dan sejenisnya. Demikian juga data sekunder di peroleh dari jurnal dan media sosial yang telah terpublikasi 
baik media cetak maupun media elektronik.

\subsection{Metode Pengumpulan Data}

Metode pengumpulan data di peroleh dengan a) Wawancara terbuka atau tidak menggunakan kuesiner dilakukan dengan Informa Kunci yaitu :Kepala Dinas Pertanian Tanama Pangan dan Hortikultura Kabupaten Karo dan Balai Penyuluhan Pertanian Kecamatan Berastagi. Kepala Dinas Sosial dan Tenaga Kerja Kabupaten Karo dan UPT Tenaga Dinas Sosial dan Tenaga Kerja atau pejabat yang berkewenangan yang mewakili.

Disamping wawancara dengan Informan Kunci juga dilakukan wawancara juga dilakukan dengan informan pendukung yaitu camat. Kepala desa / lurah, pemilik ladang / kebun serta buruh tani itu sendiri, Kepala Desa Selain wawancara tidak terstruktur di lakukan obervasi (pengamatan) lapangan tentang aktivitas buruh tani haria lepas. Demikian juga dilakukan studi litratur dari bukubuku, jurnal yang ada di baik di media cetak dan eklektronil. Serta Studi dokumentasi juag akan membantu terhadap analisi yang di lakukan oleh buruh tani harian lepas ini.

\subsection{Analisis Data}

\section{Analisa data di gunkan dalam penelitian} ini adalah :

a. Analisis Pendapatan : yang terdiri dari Pendapatan Utama sebagai buruh tani, pendapatan sambilan utma (tambahan penghasilan dari sektor pertanian, serta pendapatan sambilan dari luar pertanian.

b. Analisis Kebijakan yaitu suatu analisis tentang perlindungan terhadap buruh tani harian lepas yang dilakukan oleh pemerintah daerah sebagai pejabat publik.

\subsection{Kerangka Berpikir}

Dari uraian di atas maka dalam penelitian ini Kerangka berpikir ini dapat di jelaskan melalui kerangka berpikir berikut ini :

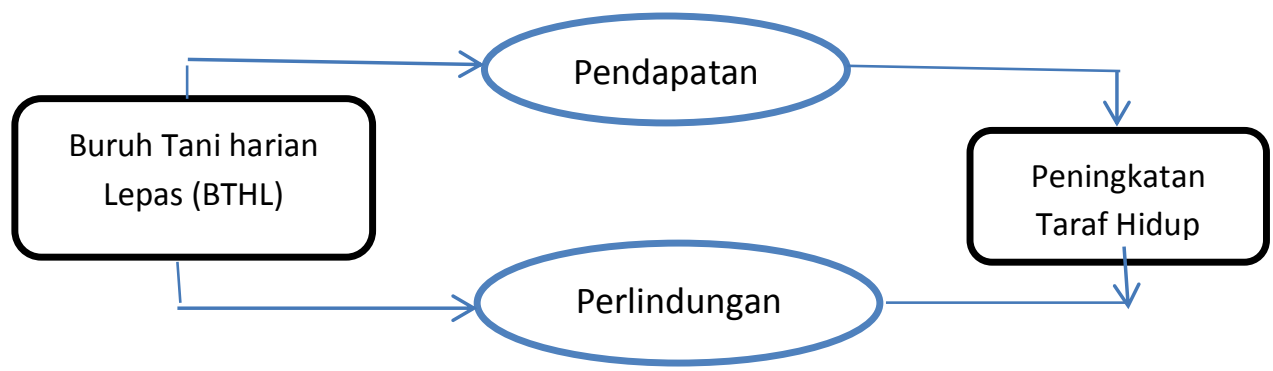

Gambar 2. Kerangka Pikiran di disain peneliti (2020)

\section{HASIL DAN PEMBAHASAN}

\subsection{Buruh Pertanian}

Informan Pendukung yaitu Camat Berastagi melalui stafnya yang menangani bahwa di Keamatan Berastagi tenaga kerja buruh tani tidak hanya masyarakat di Kecamatan Berastagi saja tetapi dari desa desa yang ada sekitar Kecamatan Berastagi khususnya Kecamatan Kaban Jahe, Kecamatan Simpang Empat, Kecamatan
Merdeka dan Kecamatan Dolat Rakyat. Dengan kemudahan arus informasi dari kota berastagi ke desa desa sekitarnya tentang informasi kesempaan kerja, demikian juga lancarnya transportasi dari desa desa tersebut menuju kota Berastagi menyebabkan lalu lintas buruh harian ini semakin mobail.

\subsection{Jenis Pertanian}


Para buruh tani harian lepas (BTHL) ini bekerja sebagai buruh di sektor pertanian dari berbagai jenis komoditas khususnya hortikultura seperti buah, sayuran dan bunga bungaan walaupun ada juga di perkebunan kopi dan kakao. Berdasarkan hasil observasi lapangan maka berbagai jenis tanaman pangan yang dominan di kecamatan Berastagi adalah : jagung (Zea mayes), ubi jalar (Pomoea batatasi), kentang (Salanum tuberosum), berbagai jenis tanaman Petsai (sawi putih, kol, kubis) dan sejenisnya ; buah terutama jeruk dan markisa serta bunga bungaan khususnya jenis krisantin dengan konsentarsi utama adalah di jalan Udara Berastagi menuju Kecamatan Simpang Empat, sepanjang jalan Djamin Ginting menuju Kecamatan Kaban Jahe, sepanjang jalan ke arah Taman Hutan Rakyat (Tahura) dan menuju kearah Kecamatan Merdeka.

\subsection{Jenis Buruh Tani Harian Lepas (BTHL)}

Kecamatan Berastagi yang merupakan daerah penelitian ini terletak di Kabupaten Karo yang sangat banyak mempekerjakan buruh tani yang dalam penelitian ini dapat dikelompokkan kepada tiga yaitu buruh tani utama yaitu buruh tani sayur sayuran (BTSy) buruh tani buah buahan (BTBh) dan buruh tani bunga bungaan $(\mathrm{BTBb})$. Dalam penelitian ini buruh tani di bagi dalam ketiga kelompok buruh tani ini saling beririsan yaitu sebagai buruh tani sayur sayuran juga sebagai beruh tani buah buahan dan juga ada yang merangkap buruh tani bunga bungan. Untuk itu dalam penelitian ini seseorang buruh tani disesuaikan berdasarkan yang dominan baik dari segi pendapatan maupun alkokasi waktu yang dicurahkan,

Dari desa desa yang ada di Kecamatan Berastagi maka yang di ambil keterangan secara sebanyak 30 orang masyarakat tanpa membedakan karakteristiknya karena tujuannya hanya untuk mendapatkan gambaran secara kualitatif yang di analisis secara diskriftif.
Adapun ke 30 BTHL tersebut terdiri dari 10 buruh tani buah (BTBh), 10 buruh tani sayur (BTSy) sert 10 lagi buruh tani bunga (BTBg). 1Adapun konsentarisi BTHL tersebut di konvermasi saat obervasi lapangan saat berada di sekitar jalan Udara mulai dari Tugu Kol Berastagi sampai Simpang Empat yang di dominasi oleh kegiatan buruh tani sayur dan buah dan sekitar jalan Djamin Ginting mulai dari Tugu mejuah Juah Berastagi sampai Taman Hutan rakyat (Tahura) yang di dominasi BTHL bunga bungaa.

\subsection{Sistem Pengupahan}

Di Kecamatan Berastagi ikatan perjanjian di buat belum formal, hanya berdasarkan rasa kepercayaan dan kebiasaan setempat yang di fasilitasi oleh orang semacam agen yang mempertemukan antara pengguna jasa dengan buruh tani pertanian. Hubungan tersebut sudah melembaga khususnya buruh tan yang di upah berdasarkan mingguan dan atau bulanan.

Upah merupakan suatu faktor yang penting bagi pekerja, karena bagaimanapun juga upah bagi pekerja merupakan tempat bergantung akan kelangsungan hidupnya, jadi upah merupakan hal yang sangat penting bagi pekerja sehingga mereka mau bekerja semata-mata hanya karena adanya upah tersebut. Di Kecamatan Berastagi terdapat berbagai aktivitas seperti pertanian, industri kecil , pariwisata dan lain sebagainnya. Salah satunya yang banyak menggunakan buruh adalah sektor pertanian berupa buruh tani dalam jumlah yang cukup besar baik bekerja di komiditi sayur sayuran, buah buahan dan bunga bungaan.

\subsection{Pendapatan Buruh Tani}

Dari hasil pengamatan (observasi) lapangan BT harian lepas ini bekerja juga bidang pertanian lain yaitu menjual sayur keliling, jualan gorengan hasil pertanian seperti goreng ubi dan pisah dekat tempat tinggalnya. Juga ada pendapatan 
sampingan lainnya sebagai pedagang minuman dan rokok keliling, buruh bangunan (kenek) dan sejenisnya.

Berbeda dengan buruh sayur sayuran yang relatif lebih banyak waktu kerjanya sementara buruh tani buah buahan dan buruh tani bungabungan lebih banyak bekerja pada akhir minggu yaitu hari jumat, sabtu dan minggu serta hari libur karena lebih banyak pengunjung dan konsumen. Khusus hari jumat adalah untu persiapan hari berikutnya yaitu sabtu dan minggu di samping untuk pembersihan juga untuk membantu pemilik mengangkat hasil buah buahan dan bunga bungaan yang di beli oleh pengunjung.

Tingkat Pendapatan Keluarga baik buruh tani sayur (BTSy), buruh tani buah

Tabel 1: Pendapatan Buruh Tani Harian Lepas Kecamatan Berastagi, 2020

\begin{tabular}{|l|r|r|r|r|}
\hline No. & Jenis BTHL & $\begin{array}{c}\text { Pend. Tertinggi } \\
(\mathrm{Rp})\end{array}$ & $\begin{array}{c}\text { Pend.Terendah } \\
(\mathrm{Rp})\end{array}$ & $\begin{array}{c}\text { Pend. Rata2 } \\
(\mathrm{Rp})\end{array}$ \\
\hline 1. & Pend. BTSy & $2.507 .345,-$ & $2.180 .965,-$ & $2.375 .000,-$ \\
\hline 2. & Pend. BTBb & $2.876 .008,-$ & 2.267 .765 & $2.556,700,-$ \\
\hline 3. & Pend, BTbg & $2,676.775,-$ & $2.245 .00 .-$ & $2.450 .762,-$ \\
\hline
\end{tabular}

Sumber : data Primer 2020.

Dari 30 keterangan yang di observasi dan wawancara menggunakan kuesener menunjukkan bahwa untuk buruh tani sayur sayura pendapatan tertinggi adalah Rp. 2.507.345,- terendah adalah Rp. 2.180.965,- dengan rata rata pendapatan sebesar Rp. 2.375.000,--

Tabel. 2. Sumber Pendapatan Buruh Tani Kecamatan Berastagi, 2020

\begin{tabular}{|l|l|c|c|c|l|}
\hline No. & Jenis Buruh & \multicolumn{1}{|c|}{$\begin{array}{c}\text { Pend Total } \\
(\mathrm{Rp}) / \%\end{array}$} & $\begin{array}{c}\text { Pend Utama } \\
(\mathrm{Rp})\end{array}$ & $\begin{array}{c}\text { Pend Sam Ut } \\
(\mathrm{Rp})\end{array}$ & \multicolumn{1}{c|}{$\begin{array}{c}\text { Pend. Sam } \\
(\mathrm{Rp})\end{array}$} \\
\hline 1. & Brh BTSy & $2,375.000 / 100.00$ & $.1 .800,750 / 75.82$ & $410.000 / 17.26$ & $164.245 / 06.92$ \\
\hline 2. & Brh BTBb & $2.556,700 / 100,00$ & $2.236 .601 / 87.48$ & $231.669 / 09,06$ & $117.17 / 04.78$ \\
\hline 3. & Brh BTBg & $2.450 .762 / 100,00$ & $2.001,924 / 81.69$ & $331.669 / 13.53$ & $117.169 / 04.78$ \\
\hline
\end{tabular}

Sumber : Hasil dari lapangan, 2020
Adapun pendapatan rata rata dari 30 sampel buruh tani sayur sayuran (BTSy) sebesar Rp. 2,375.000,- $(100,00)$ yag bersumber dari 3 komponen unsur pendapatan yaitu dari pendapatan Utama yaitu yang relatif rutin sebagai buruh tani sayur sayuran sebesar Rp. 1.800,750,$(75.82 \%)$, dari pendapatan tambahan sebagai pekerjaan sambilan utama yaitu buahan $(\mathrm{BTBb})$ maupun buruh tani bunga bungaan (BTBg) menunjukkan perbedaan yang tidak terlalu tinggi, Pendapatan yang dihitung ini adalah pendapatan total yang merupakan akumulasi dari pendapatan utama, pendapatan sambilan utama dan pendapatan sambilan. Hasi rata rata pendapatan tersebut yaitu di hitung pendapatan buruh tani sayur sayuran ( BTSy) sebesar Rp 2,375,000n(pembulatan), buruh tani buah buahan (BTBb) sebesar Rp. 2.556.700,(pembulatan) serta pendapatan dari buruh tani bunga bungaan (BTBg) sebesar Rp. 2.450.762,- (pembulatan), yang selengkapnya dapat dilihat pada Tabel berikut :"
Dari sisi struktur pendapatan maka untuk ke tiga jenis buruh tani pendapatan utama dari buruh tani sayur sayuran, buah buahan dan bunga bungan di atas $75 \%$. Sebagaimana tergambar pada tabel berikut 
pendapatan rata rata $\mathrm{BTBb}$ sebesar $\mathrm{Rp}$. $2.556,700,-(100,00)$ yang bersumber dari pendapatan sebagai pendapatan total merupakan pendapatan kumulatif dari pendapatan Utama sebesar Rp. 2.236.601,(87.48\%), pendapatan sambilan dari buruh pertanian dari sambilan utama sebesar Rp. $231.669,-(09,06 \%)$ dan pendapatan sambilan sebagai buruh tani non pertanian sebesar Rp. 111.570,- (04.37 \%)

Demikian juga pendapatan BTBg sebesar Rp. 2.450.762,- $(100,00)$ sebagai pendapatan total merupakan pendapatan kumulatif dari pendapatan Utama sebesar Rp. $2.001,924,-(81.69 \%)$, pendapatan dari sambilan utama dari pertanian lainnya sebesar Rp.331.669,- (13.53 \%) dan pendapatan sambilan yaitu buruh tani dari luar pertanian sebesar Rp. 117.169,- (04.78 $\%)$.

Dari hasil pada tabel tersebut menunjkkan bahwa rata rata pendapatan terbesar adalah buru tani buah buahan kemudian Rp. 2.556,700,- kemudian disusul terbesar kedua adalah buruh tani bunga bungaan sebesar 2.450.762,- dan yang paling kecil adalah buruh tani sayur sayuran yaitu sebesar 2,375.000,-. Demikian juga dari segi persentase sumber pendapatan maka untuk $\mathrm{BTBb}$ sebesar $87.48 \%$ dari pendapatan utama kemudian $09.06 \%$ dari sambilan utam pertanian sedangkan hanya $4.37 \%$ dari pendapatan sambilan non pertanian. Komposis untuk BTSy dari pendapatan utama sebeesar $75,82 \%$, disusul pendapatan dari sambilan utama pertanian sebesar $17,26 \%$ dan dari sambilan non pertanian sebesar $06.92 \%$.

\subsection{Perlindungan Buruh}

Dari pengamatan di lapangan bahwa apa yang di sampaikan oleh mantan Menteri Tenaga Kerja ini juga terjadi di Kecamatan Berastagi dimanan anatara buruh tani harian lepas (BTHL) ini hubungan kerja BTHL dan majikannya yang tidak terdokumentasi. Tidak ada di temukan catatan catatan baik di majikan maupun di BTHL tersebut. Semua terjadi atas kesepakatan lisan awal termasuk lama kerja, jenis kerja dan sistem pengupahan.

Demikian juga dengan masa kerja dua tahun sampai dengan upah buruh yang masa kerjanya sudah 15 tahun tidak di temukan ada suatu mekanisme yang mengikat tentang kenaikan upah dikaitkan dengan masa kerja. Semua berjalan sesuai dengan perjanjian lisan tanpa adanya suatu dokumen dokumen. Tawar menawar upaha an sistem pembayaran sesuai dengan kesepakatan antar mereka.

Hasil observasi lapangan menunjukkan bahwa mayoritas buruh tani yang dijumpai adalah kaum perempuan. Satu fenomene yang di peroleh bahwa terdapat juga buruh tani perempuan ini yang suda terikat dengan salah satu majikan karena ada hubungan hutang piutang. Berdasarkan keterangan yang di peroleh hal ini di lakukan karena buruh tani harian lepas mendapatkan kebutuha yang tiba tiba untuk keperluan keluarga (pendidikan, pengomatan, dan juga untuk pembelian perabotan dan peralatan rumah tangga,

Dari hasil pantauan dan pengamatan lapangan menunjukkan bahwa dalam rangka program kesejahteraan berdasarkan informan pendukung baik dari kecamatan maupun kelurahan / desa yang sudah berjalan adalah pelayanan keluarga berencana di Puskesmas pembantu yang ada di desa maupun Puskesmas yang ada di kecamatan. Penitipan anak belum ada di sediakan oleh Pemerintah setempat tapi yang ada adalah swadya masyrakat dengan menempung anak anak titipan di rumahnya atas jasa kekeluargaan ata bayaran tertentu,

Pasilitas perumahan yang di sediakan khusus untuk buruh belum tersedia di Kecamatan Berastagi. Para buruh menempati tempat tinggal dengan swadaya masing masing sesuai dengan kemampuannya. Ada yang tinggal menumpang sementara, mencari rumah kontrakan yang di tempati secara bersama sama atau juga ada yang membuat bangunan tambahan di saming atau di belakang rumah tertentu atas ijin pemeilik 
rumah tapi khusus untuk laki laki ada juga yang membangun tempat tinggal semantara di tanah kosong atau di lahan / kebun milik seseorang.

Demikian juga dengan fasilitas kesehatan bahwa kewajiban untuk menjadi asuransi tenaga kerja baru pada perusahaan perusahaan yang telah memilik badan hukum, sementara untuk buruh tani yang sifatnya insidentil tidak ada kewajiban akan hal tersebut. Diperlukan suatu sistem dan mekanisme agar para buruh khususnya buruh tani harisn lepas ini masuk dalam keanggotaan asuransi tenaga kerja yang di kelola oleh BPJS. Dari informan pendukung yang menangani asuransi BPJS di kecamatan di peroleh informasi bahwa pendataan buruh tani harian lepas ini mengalami kesulitan karena mobilitasnya sangat tinggi

Berdasarkan informasi dari petugas yang menangani ketenaga kerjaan di Kecamatan Berastagi ketentuan ketentuan sebagaiman di sebut di atas baru terlaksana di perusahaan - perusahaan pertanian dan pariwisata di Berastagi seperti agrowisata Susu Segara, taman Bunga Berastagi, Perternakan sapi, Pengolahan Markisa dan sejennisnya di mana banyak yang mempekerjakan buruh tani harian lepas tapi tidak menjadi objek dalam penelitian ini .

Untuk hal ini diperlukan suatu bentuk perlindungan khususnya perlindungan tentang kesehatan buruh tani harian lepas ini dalam bentuk regulasi yang lebih sederhana karena keadaan mereka dalam pihak yang lemah termasuk dalam pengetahua, pembiayaan, dan akses terhadap informasi informasi agar amanah Undang Undang tentang kewajiban negara melindungi segenap bangsa Indonesia dan seluruh tumpah darah Indonesia bukan hanya ancaman dari luar Negara melainkan juga ancaman dari dalam misalnya wabah penyakit, kemiskinan, bencana alam dan lain sebagainya.

Penyuluhan penyuluhan ini juga melibatkan beberpa agen dn pusat informasi tenega kerja / buruh yang ada di desa / kelurahan Kecamatan Berastagi. Hal yang sering di sosialisasikan adalah yang berhubunungan tentang hak hak pekerja / buruh di mana sudah ada Upah Minimum Kabupaten (UMK) yang di kabupaten Karo di tetapkan Rp. 2.070.000,- per kabupaten pada tahun 2020.

Selain langkah langkah sosialisasi tersebut terdapat juga pelatihan agar buruh tani ini juga dapat meningkatkan ketrampilannya bidang usaha rumah tanggga agar selain sebagai buruh tani dapat juga menggunakan waktu luangnya untuk belajar membuat kue / makanan, kering serta usaha lain seperti menjahit dan membuat cidra mata yang juga tersedia lapangan kerja.

\section{SIMPULAN \\ Simpulan}

Tingkat Pendapatan BTSy, BTBb maupun BTBg menunjukkan perbedaan yang tidak terlalu tinggi. Hasil rata rata, pendapatan BTSy sebesar Rp 2,375,000- BTBb sebesar Rp. 2.556.700,- BTBg sebesar Rp. 2.450.762,- (pembulatan).Adapun pendapatan rata rata BTSy sebesar Rp. $2,375.000,-(100,00)$ yang terdiri dari pendapatan Utama sebesar Rp. 1.800,750,(75.82\%), dari pendapatan tambahan sambilan utama yaitu sebesar Rp. 410.000,- $(17.26 \%)$ dan pendapatan sambilan sebesar Rp. 164.245,- (06.92 \%).

Adapun sumber pendapatan rata rata BTBb sebesar Rp. 2.556,700,- $(100,00)$ yang terdiri dari pendapatan Utama sebesar Rp. 2.236.601,- (87.48\%), pendapatan sambilan utama sebesar Rp. 231.669,- $(09,06 \%)$ dan pendapatan sambilan non pertanian sebesar Rp. 111.570,- (04.37 \%). Pendapatan BTBg sebesar Rp. 2.450.762,- $(100,00)$ terdiri dari pendapatan Utama sebesar Rp. 2.001,924,- (81.69\%), pendapatan dari sambilan utama Rp.331.669,- (13.53\%) dan pendapatan sambilan dari luar pertanian sebesar Rp. 117.169,- (04.78 \%). Perlidungan yang di lakukan Pemerintah Kabupaten Karo terhadap buruh harian lepas sesuai dengan Pasal 99 (1) baru 
terlaksana pada pelayanan Keluarga Berencana sementara Penitipan Anak dan pembuatan Pemukiman Buruh baru pada tahap rencana.Perlindungan sebagaimana di maksud dalam Undang Undang Nomor 24 tahun 2011 tentang Badan Penyelenggraan Jaminan Sosial (BPJS) baik Jaminan Kesehatan dan Jaminan Ketenagkerjaan terhadap Buruh Tani harian Lepas (BTHL) yang bekerja di perusahaan dan belum mengatur tentang BRHL yang bekerja di usaha perorangan atau rumah tangga.

\section{Saran}

Dinas Sosial dan Tenaga Kerja agar mengadakan pendataan terhadap semua Buruh Tani harian Lepas (BTHL) baik yang berdomisili di Kecamatan Berastagi maupun di luar Kecamatan Berastagi bekerja sama dengan agen agen tenaga kerja / buruh dan jasa informasi pelayanan tenaga kerja / buruh yang ada di Kecamatan Berastagi..Khususnya untuk BTHL yang tinggal di Kota Berastagi agar Pemerintah menata pemukiman sehingga terhindar dari pemukiman kumuh.

Sudah saatnya Pemerintah Daerah melalui pemrintah kecamatan / desa / kelurahan membuat tempat penitipan anak bagi buruh tani harian lepas yang sebagian adalah peremupan sehingga terjamin keamanan dan kenyamanannya.

Untuk menjaga lingkungan kota yang nyaman dari permukiman kumuh mencegah tingkat kriminalitas serta dampak sosial negatif lainnya Pemerintah Daerah dapat membangun atau memfasilitasi pembangunan pemukiman untuk kaum buruh.

\section{DAFTAR PUSTAKA}

Fathoni, Abdurrahmat, 2006, Metodologi Penelitian \& Tehnik Penyusunan Skripsi, Jakarta: PT. Rineka Jaya.

Balai Penelitian dan Pengembangan Pelayanan Kesejahteraan Sosial (B2P3KS). Analisis Perlindungan jaminan Sosial bagi Pekerja Informal. Jogyakarta.
Lusiana Dewi Agustin (2017) Perlindungan Hukum Dalam pemberian Upah dan peningkatan Kesejahteraan Buruh di Area Moebel. Universitas Muhamaddyah Surakarta.

Soekartawi, 1986, Ilmu Usaha Tani dan Penelitian Untuk Pengembangan Petani Kecil, UI - Press, Jakarta.

Soekartawi., 1993, Agribisnis Teori dan Aplikasinya, Raja Garfindo Persada, Jakarta.

Suciati (2016) Perlindungan Hukum terhadap Petani dalam Menggapai Negara Kesejahteraan (Wellfare State) . Universias Kanjurahan Malang. Malang.

Perkembangan Ekonomi Pertanian Nasional, Perhimpunan Ekonomi Pertanian Indonesia, Jakarta. Trubus, redaksi., 1998, Tanaman Hias Indoor Populer, Penebar Swadaya, Jakarta.

Rahmat K. 2006. Teknik Praktis Riset Komunikasi. Jakarta : PT. Kencana Perdana. Liliweri,

Rivai, Veithzal. 2014. Manajemen Sumber Daya Manusia. Jakarta: PT Raja Grafindo Persada.

Morissan, 2013. Teori Komunikasi Individu Hingga Massa. Jakarta : PT . Kencana Prenada Media Group,

Rizky Dianita (2017) tentang Analisis Pola Konsumsi keluarga Buruh Tani Singkong dan Buruh Penyedap Karet di Lampung (Jurnal). Universitas Lampung. Bandar Lampung.

Siagian, Sondang P. 2015. Manajemen Sumber Daya Manusia. Jakarta: PT Bumi Aksara Sudijono, Anas. 2009. Pengantar Statistik Pendidikan. Jakarta: Raja Grafindo Persada

Teori Komunikasi Tentang Komunikator, Pesan, Percakapan, dan Hubungan (Interpersonal). Bogor : PT Ghalia Indonesia. 